\title{
Integrated pest control adopted by soybean and corn farmers in Londrina, Paraná state, Brazil
}

\author{
Controle integrado de pragas adotado por produtores de soja e \\ milho em Londrina, Paraná, Brasil
}

\section{Marcela Laiz Mora Grande ${ }^{1 *}$, Jael Simões Santos Rando'}

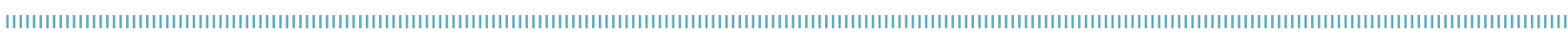

\begin{abstract}
The metropolitan area of Londrina has the presence of strong agribusiness and agroservices and it is an important center for agricultural production, especially soybean and corn. We evaluated the technical aspects and characteristics of farming and crop handling by the producers of soybean and corn, through a semi-structured questionnaire. Two hundred and forty responses were recorded: 120 from soybean farmers and 120 from corn farmers, which represented $10 \%$ of the farmers in the city of Londrina. Farmers reported that bedbugs and caterpillars are the main pests. Farmers use organo-synthetic insecticides as the primary means to control pests, but also employ cropgrowing measures such as tillage, crop rotation, and the use of transgenic seeds in the management of insect pests affecting soybean and corn.
\end{abstract}

KEYWORDS: chemical control; Glycine max L.; insects, Zea mays L.
RESUMO: A região metropolitana de Londrina tem forte presença no mercado de agronegócios e agroserviços, sendo um importante centro de produção agrícola, especialmente de soja e milho. $\mathrm{Na}$ pesquisa, foi utilizado um questionário semiestruturado para avaliar os aspectos técnicos e as características de cultivo e manejo de culturas pelos produtores de soja e milho na regiáo, com ênfase nas estratégias usadas para o controle de pragas. Foram registradas 240 respostas: 120 de produtores de soja e 120 de plantadores de milho, o que representou $10 \%$ dos agricultores da cidade de Londrina. Os agricultores relataram que percevejos e lagartas são as pragas mais comuns que atacam suas culturas. Como o principal meio para controle, são aplicados inseticidas organossintéticos, mas também são empregadas medidas de cultivo, como o preparo do solo, a rotaçáo de culturas e o uso de sementes transgênicas no manejo de pragas de insetos que afetam a soja e o milho.

PALAVRAS-CHAVE: controle químico; Glycine max L.; insetos; Zea mays L. 
In Brazil, the production of corn and soybean accounts for about $80 \%$ of the country's grain production, and the state of Paraná is the largest national producer of these grains (IPARDES, 2012).

The incidence of pest infestations in soybean and corn crops, from germination to harvest, can compromise grain yield and quality, causing crop damage, with significant economic loss (LIMA et al., 2010). Thus, the present study aimed to identify the management measures that soybean and corn producers in Londrina, Paraná, use to control pests.

This study was carried out in 2013 in the rural area of the municipality of Londrina, located in the north of the state of Paraná, Brazil, at $23^{\circ} 18^{\prime} 0^{\prime \prime} \mathrm{S}$ and $51^{\circ} 9^{\prime} 0^{\prime \prime} \mathrm{W}$, at an altitude of $610 \mathrm{~m}$ and with area of $1,652 \mathrm{~km}^{2}$.

The research instrument was a semi-structured questionnaire, containing questions with dichotomous responses, multiple-choice responses, and fact- and opinion-based responses (BARROS; LEHFELD, 2000). The target audience was 240 farmers that account for $10 \%$ of the rural producers of soy and corn, according to Londrina's city hall.

Information was sought on the system of cultivation, seed selection, and pesticide use by farmers. Concerning pest management, producers were asked to list the insects that occur in the soil and on the aerial parts of soybean and corn crops, and were asked about their perceived importance of these insects in relation to the crop.

In order to assist the producers in the identification and recognition of pests and natural enemies, entomological boxes were used, one for each culture studied (Table 1). Excel ${ }^{\circ}$ software was used to organize the database and, from this, descriptive and exploratory statistics were determined for the analysis.

\section{SOY CULTURE}

Producers seek to acquire certified and genetically improved seeds. Ninety-nine percent of farmers reported using transgenic seeds. Knowledge about soybean cultivation was acquired through field days (32\%), technical assistance $(28 \%)$, technical meetings (24\%), and information exchange (16\%).

Decision making on pest control is largely aided by a technician, and $97 \%$ of producers use technical assistance. This trend is also seen in purchase of insecticides: $68 \%$ of producers follow the advice of a technician, $23 \%$ take into account the price, $5 \%$ the quality of the product, and $4 \%$ the recommendations of known producers.

Approximately $10 \%$ of farmers produce up to $2,701 \mathrm{~kg} / \mathrm{ha}$ of soybeans and $90 \%$ produce more than $2,701 \mathrm{~kg} / \mathrm{ha}$. Regarding the cultivation system, this study verified unanimity among the soybean farmers in the management of crops with no-tillage.
Table 1. Percentage of insect pests and natural enemies recognized by soybean and corn producers in Londrina, Paraná, Brazil, 2013.

\begin{tabular}{|c|c|c|}
\hline \multirow{2}{*}{ Insect pests } & \multicolumn{2}{|c|}{ Percentage } \\
\hline & Soy & Corn \\
\hline Chinavia spp. & 2.78 & - \\
\hline Oebalus spp. & 1.68 & - \\
\hline Epicauta atomaria (Germar, 1821) & 4.72 & - \\
\hline Anticarsia gemmatalis (Huebner, 1818) & 5.37 & - \\
\hline Atta sp. & 3.17 & 6.70 \\
\hline Lagria villosa (Fabricius, 1783) & 3.62 & 7.35 \\
\hline Phyllophaga spp. & 4.66 & - \\
\hline Neomegalotomus parvus (Westwood, 1842) & 3.04 & - \\
\hline Sternechus subsignatus (Boheman, 1836) & 4.53 & - \\
\hline Nezara viridula (Linnaeus, 1758) & 6.21 & 9.40 \\
\hline Diabrotica speciosa (Germar, 1824) & 4.98 & 8.28 \\
\hline Urbanus proteus (Linnaeus, 1758) & 3.75 & - \\
\hline Leptoglossus zonatus (Dallas, 1852) & 3.62 & 6.51 \\
\hline Dichelops furcatus (Fabricius, 1775) & 5.88 & 8.47 \\
\hline Cerotoma sp. & 2.07 & - \\
\hline Maecolaspis spp. & 4.40 & 6.79 \\
\hline Aracanthus mourei (Rosado Neto, 1981) & 3.49 & - \\
\hline Pseudoplusia includens (Walker, 1857) & 5.24 & - \\
\hline Euschistus heros (Fabricius, 1794) & 7.31 & 9.96 \\
\hline Piezodorus guildinii (Westwood, 1837) & 5.50 & - \\
\hline Edessa meditabunda (Fabricius, 1974) & 6.20 & 8.47 \\
\hline Proxys sp. & 3.04 & - \\
\hline Diphaulaca sp. & - & - \\
\hline Conoderus scalaris (Germar, 1824) & - & 6.70 \\
\hline Euxesta eluta (Loew, 1868) & - & 5.86 \\
\hline Helicoverpa zea (Boddie, 1850) & - & 6.33 \\
\hline Diatraea saccharalis (Fabricius, 1794) & - & - \\
\hline Spodoptera frugiperda (J. E. Smith, 1797) & - & 9.12 \\
\hline Omiodes indicata (Fabricius, 1775) & 4.78 & - \\
\hline \multicolumn{3}{|l|}{ Natural enemies } \\
\hline Podisus nigrispinus (Dallas, 1851) & 14.18 & - \\
\hline Harmonia axyridis (Pallas, 1773) & 22.18 & - \\
\hline $\begin{array}{l}\text { Hippodamia convergens (Guérin-Méneville, } \\
\text { 1842) }\end{array}$ & 15.63 & 17.0 \\
\hline Calosoma sp. & 14.18 & - \\
\hline Alcaeorrhynchus grandis (Dallas, 1851) & 13.09 & 11.8 \\
\hline Chrysoperla sp. & 20.72 & 10.8 \\
\hline Doru luteipes (Scudder, 1876) & - & 18.6 \\
\hline Rasahus hamatus (Fabricius, 1781) & - & 7.8 \\
\hline Lebia concinna (Brulle, 1838) & - & - \\
\hline Naemia maculata (De Geer, 1775) & - & 15.8 \\
\hline Eriopis connexa (Germar, 1824) & - & 9.6 \\
\hline Orius sp. & - & 8.6 \\
\hline
\end{tabular}


Producers use seeds treated with insecticides, with a preference for neonicotinoids (37\%) and fipronil (33\%). About 20\% of producers use a commercial mixture of imidacloprid and thiodicarb, 3\% use abamectin, and 7\% use various active principles.

Soil insect pests in recent years comprised Phyllophaga sp. (20.12\% of respondents), the Elasmopalpus lignosellus and Agrotis ipsilon caterpillars (18.86\% each), and the so-called snake lice, considered as a pest by $14.46 \%$ of the interviewees. In relation to the pest insects of the aerial part of the crops, the greatest damage to the crops was attributed to caterpillars and stink bugs (without defining the species), by 43.41 and $42.63 \%$ of the farmers, respectively.

Another pest cited during the research that has caused large agricultural losses is the caterpillar Helicoverpa armigera (CZEPAK et al., 2013). The producers' concern with this caterpillar is notable, since $84 \%$ of the respondents said they had already been informed about it, and, of these, 33\% had already found it on their property. The $H$. armigera caterpillar has a polyphagous habit: $83 \%$ of the producers reported its occurrence on soybean, $11 \%$ on corn, and $6 \%$ on wheat.

The timing of pest control is decided by approximately $60 \%$ of farmers through monitoring. The ground cloth method is used by $66 \%$ of respondents before making pest control decisions, $2 \%$ use the level of defoliation, and $32 \%$ prefer to make applications preventively. Of those who perform monitoring, $60 \%$ are accompanied by a technician at the time of sampling, and $40 \%$ perform monitoring by themselves. The ground cloth method is used for the monitoring of defoliating caterpillars, seed sucking insects, and insects in general, including some natural enemies present in soybean (CORREA-FERREIRA, 2012).

To control overhead pests, $80 \%$ of farmers apply up to three sprays with insecticides for bedbugs and $72 \%$ use the same for caterpillars. The insecticides chosen for foliar spray by the respondents are shown in Figure 1. Of the chemical insecticides used in soybean cultivation, $61 \%$ of producers believe that they affect natural enemies, $20 \%$ do not believe that they have effect, and $19 \%$ said they have not noticed changes.

Sixty-one percent of farmers responded that they had never used biological control and 39\% had used it. Of those who had used biological control, 59\% thought it was good, $10 \%$ thought it was great, $9 \%$ bad and $22 \%$ regular. Although respondents were not questioned about the nature of their academic career, $38 \%$ of producers who had a higher education degree had a degree in Agricultural Sciences. These results point to the abandonment of many of the principles of integrated pest management, which has biological control at its foundation by those that should be its main advocates. This conclusion is reinforced by the finding that the same percentage of producers who recognize the negative effects of insecticides on natural enemies have not sought the advantages of biological agents as an alternative control.

The brown stink bug Euschistus heros was the most widely recognized pest by respondents $(7.31 \%$ of all). Of the natural enemies, the ladybird Harmonia axyridis was the most recognized by the producers (22.18\% of respondents) (Table 1$)$. Soybean cultivation presents a large diversity of natural enemies. However, the low percentages of recognition in this study are corroborated by previous studies. RANDO; GRANDE (2013) confirmed that many soybean and corn producers are unaware of beneficial insects and their importance in agroecosystems.

\section{CORN CULTURE}

Respondents received training through field days (32\%), technical assistance (25\%), and technical meetings (23\%); 20\% of respondents exchanged information with other farmers.

The producers use genetically modified seeds, of which $71 \%$ are in areas of refuge, which is considered one of the main resistance management strategies of insect pests in crops that use Bt maize (DIGIOVANI, 2013). Crop rotation is used by $74 \%$ of the farmers interviewed, and the rotation is mainly comprised of soybeans (61\%), oats (11\%), and wheat (28\%).

Regarding insect losses, $45 \%$ of respondents said that losses were less than $5 \%$; $47 \%$ believe that losses were between 10 and $20 \%$; and only $8 \%$ stated that losses were higher than $20 \%$.

One of the alternatives for minimizing the action of pests and preventing productivity losses is the use of insecticides seed treatment. The economic return of treating seeds with insecticides in corn crops is compensatory (CECCON et al., 2004). The insecticides used by the farmers in seed treatment are described in Figure 2.

In order to control the pests of the aerial part of the corn, approximately $81 \%$ of the interviewees make up to three applications of insecticides via foliar spraying. For treatment of caterpillars,

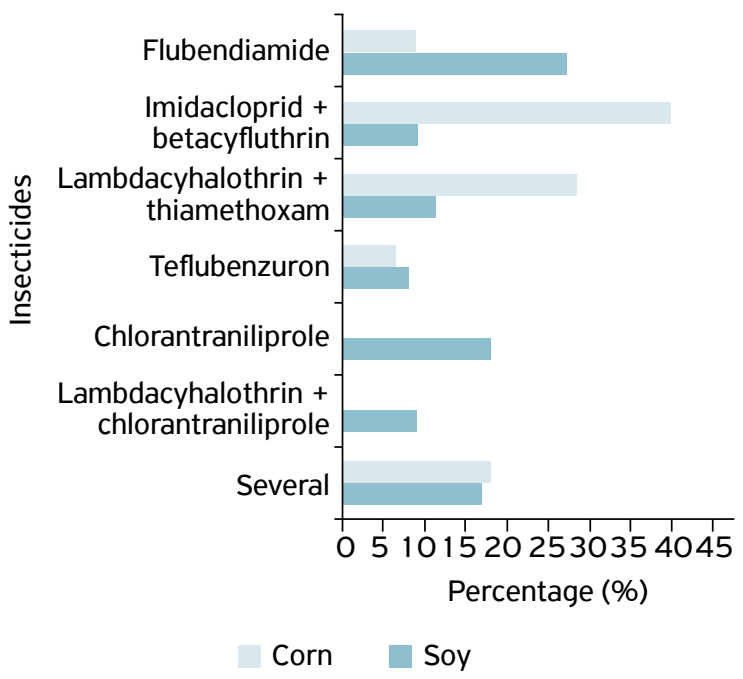

Figure 1. Percentage of insecticides (flubendiamide; imidacloprid + betacyfluthrin; lambdacyhalothrin + thiamethoxam; teflubenzuron; chlorantraniliprole; lambdacyhalothrin + chlorantraniliprole; others) used in foliar spraying for pest control by soybean and corn producers in Londrina, Paraná, Brazil, 2013. 


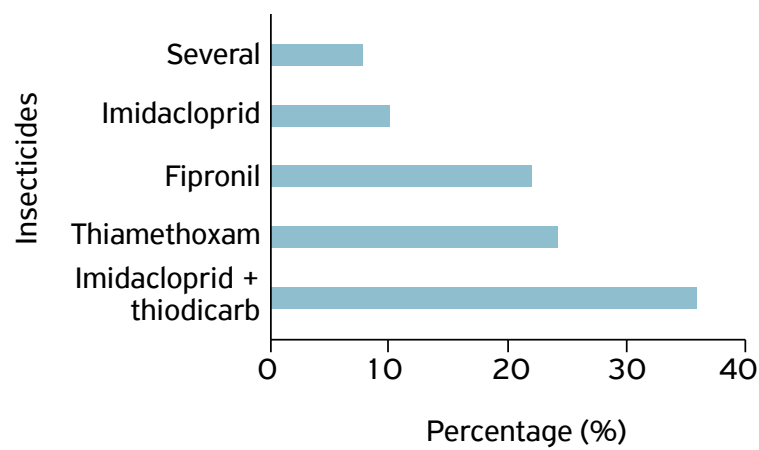

Figure 2. Percentage of insecticides (imidacloprid+thiodicarb; thiamethoxam; fipronil; imidacloprid; several) used by corn producers in Londrina, Paraná, Brazil, 2013.

$38 \%$ of respondents make a single spray with insecticide, $22 \%$ make two or more applications, and $40 \%$ do not spray. When purchasing insecticides, $68 \%$ of respondents follow the recommendations of a technician, $23 \%$ take the price into consideration, $5 \%$ consider the quality of the product, and $4 \%$ the recommendations of known producers. Thirty-one percent of producers always use the same brand of products, and $69 \%$ seek to change the brand. The insecticides used are shown in Figure 1

Forty-eight percent of farmers used pest monitoring to decide on the need for control. Visual monitoring only was cited by $40 \%$ of the participants; $13 \%$ use the level of leaf scraping; and $47 \%$ prefer to make preventive applications.
Among the various monitoring techniques used, the number of plants attacked by fall armyworm was the most reported (VIANA et al., 2004). Monitoring by $69 \%$ of the respondents are followed by monitoring by a technician, and 31\% monitored alone.

The pests that occur in the crops in the summer harvest are the same ones that are seen in the corn crops. About $32 \%$ of respondents reported not having problems with soil pests; 21.56 and $19.60 \%$ referred to the caterpillars Elasmopalpus lignosellus and Agrotis ipsilon, respectively, and $16.33 \%$ of respondents referred to white grub and $9.8 \%$ to snake lice. For pests found on the plant shoot, $48.55 \%$ of respondents reported that bedbugs (48.55\%) and caterpillars (46.24\%) were the most common. Bedbugs were the pests considered to cause the greatest damage to the crop ( $72 \%$ of respondents), followed by caterpillars (25\%). A small percentage of the farmers (3\%) attributed the losses to the Spodoptera frugiperda caterpillar.

When observing the insects in the entomological boxes, $42.81 \%$ of the producers recognized the pentatomid bugs, and $15.45 \%$ recognized the $S$. frugiperda caterpillar (Table 1). As for the natural enemies, Doru luteipes was recognized by $18.6 \%$ of the producers, followed by the ladybug Hippodamia convergens $(17 \%)$. The farmers stated that they observed the bugs (77\%) and the caterpillars (23\%) most frequently in the field.

Soybean and corn farmers adopt measures of no-tillage, crop rotation, transgenic seeds, and chemical control in the management of pest insects in soybean and corn crops in Londrina.

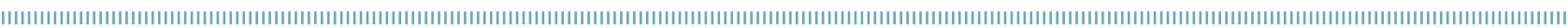
REFERENCES

BARROS, A.J.P.; LEHFELD, N.A.S. Projeto de pesquisa: propostas metodológicas. 11. ed. Petrópolis: Vozes, 2000. 102p.

CECCON, G.; RAGA, A.; DUARTE, A.P.; SILOTO, R.C. Efeito de inseticidas na semeadura sobre pragas iniciais e produtividade de milho safrinha em plantio direto. Bragantia, v.63, n.2, p.227-237, 2004. DOI: 10.1590/S0006-87052004000 200008.

CZEPAK, C.; ALBERNAZ, K.C.; VIVAN, L.M.; GUIMARÃES, H.O.; CARVALHAIS, T. First reported occurrence of Helicoverpa armigera (Hubner) (Lepidoptera: Noctuidae) in Brazil. Pesquisa Agropecuária Tropical, v.43, n.1,p.1 10-1 13, 2013. DOI: 10.1590/ S1983-40632013000100015

CORRÊA-FERREIRA, B.S. Amostragem de pragas da soja. In: HOFFMANN-CAMPO, C.B.; CORRÊA-FERREIRA, B.S.; MOSCARDI, F. Soja: manejo integrado de insetos e outros artrópodes-pragas. Londrina: Embrapa, 2012. p. 631-672.

DIGIOVANI, M.S.C. Como garantir todo potencial da tecnologia transgênica: e a necessidade de espaçamento e da área de refúgio. Boletim Informativo do sistema FAEP, 1234 , p.3-5, 2013.

INSTITUTO PARANAENSE DE DESENVOLVIMENTO ECONÔMICO E SOCIAL (IPARDES) Caderno estatístico-município de Bandeirantes. 2012. Available from: <http:// www.ipardes.gov.br.>. Accessed on: Jun. 212013.

LIMA, M.S.; SILVA, P.S.L.; OLIVEIRA, O.F.; SILVA, K.M.B.; FREITAS, F.C.L. Corn yield response to weed and fall armyworm controls. Planta Daninha, v.28, n.1, p.103-111, 2010. DOI: 10.1590/ S0100-83582010000100013

RANDO, J.S.S.; GRANDE, M.L.M. Profile of producers regarding the knowledge of pests and beneficial insects in soybean and maize in Bandeirantes-Paraná. Brazilian Journal of Applied Technology for Agricultural Science, v.6, n.3, p.77-85, 2013.

VIANA, P.A.; WAQUI, J.M.; VALICENTE, F.H.; CRUZ, I. Ocorrência e controle de pragas na safrinha de milho nas regiões Norte e Oeste do Paraná. Sete Lagoas: CNPMS, 2004. 23p. (Circular Técnica, 45). 